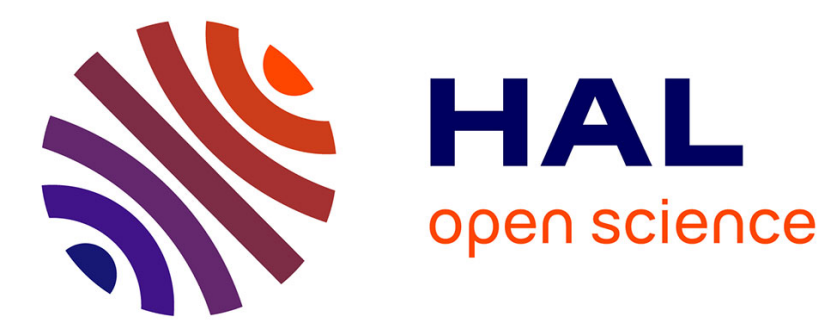

\title{
Enzymatic Activity in the Rhizosphere of : Potential Contribution for Phytoremediation of metals
}

\author{
Rosa Reboreda, Isabel Caçador
}

\section{To cite this version:}

Rosa Reboreda, Isabel Caçador. Enzymatic Activity in the Rhizosphere of: Potential Contribution for Phytoremediation of metals. Marine Environmental Research, 2007, 65 (1), pp.77. 10.1016/j.marenvres.2007.09.001 . hal-00501924

\section{HAL Id: hal-00501924 https://hal.science/hal-00501924}

Submitted on 13 Jul 2010

HAL is a multi-disciplinary open access archive for the deposit and dissemination of scientific research documents, whether they are published or not. The documents may come from teaching and research institutions in France or abroad, or from public or private research centers.
L'archive ouverte pluridisciplinaire HAL, est destinée au dépôt et à la diffusion de documents scientifiques de niveau recherche, publiés ou non, émanant des établissements d'enseignement et de recherche français ou étrangers, des laboratoires publics ou privés. 


\section{Accepted Manuscript}

Enzymatic Activity in the Rhizosphere of Spartina maritima: Potential Contri bution for Phytoremediation of metals

Rosa Reboreda, Isabel Caçador

PII:

S0141-1136(07)00112-2

DOI:

10.1016/j.marenvres.2007.09.001

Reference:

MERE 3141

To appear in:

Marine Environmental Research

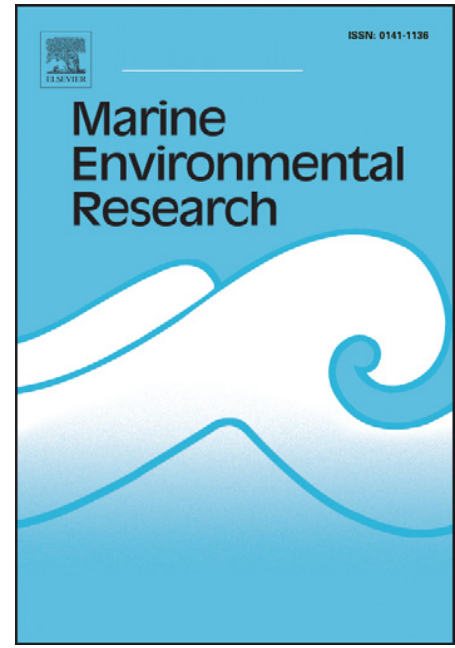

Received Date: $\quad 12$ January 2007

Revised Date: $\quad 3$ September 2007

Accepted Date: $\quad 4$ September 2007

Please cite this article as: Reboreda, R., Caçador, I., Enzymatic Activity in the Rhizosphere of Spartina maritima: Potential Contribution for Phytoremediation of metals, Marine Environmental Research (2007), doi: 10.1016/ j.marenvres.2007.09.001

This is a PDF file of an unedited manuscript that has been accepted for publication. As a service to our customers we are providing this early version of the manuscript. The manuscript will undergo copyediting, typesetting, and review of the resulting proof before it is published in its final form. Please note that during the production process errors may be discovered which could affect the content, and all legal disclaimers that apply to the journal pertain. 
1 Type of contribution: Regular paper

2 Date of preparation: June 2007

3 Text pages: 17

4 Tables: 4

5 Figures: 1

6 Title: Enzymatic Activity in the Rhizosphere of Spartina maritima: Potential

7 Contribution for Phytoremediation of metals.

8 Authors: Rosa Reboreda ${ }^{1}$ and Isabel Caçador ${ }^{2 *}$

9 Affiliations: ${ }^{1,2}$ Institute of Oceanography, Faculty of Sciences, University of Lisbon,

10 Campo Grande, 1749-016 Lisbon, Portugal

11 "Corresponding author: E-mail: micacador@fc.ul.pt Telephone +351 217500104

$12 \quad$ Fax +351217500009

$13 *$ Address for proofs

\footnotetext{
* Institute of Oceanography, Faculty of Sciences, University of Lisbon, Rua Ernesto de Vasconcelos s/n, Campo Grande, 1749-016 Lisbon, Portugal
} 


\section{ACCEPTED MANUSCRIPT}

\section{Abstract}

2

3

5

6 parameters and metal contaminant levels. Our aim was a better understanding of the

7 influence of the halophyte on microbial activity in the rhizosphere under different site

8 conditions, and its potential consequences for metal cycling and phytoremediation in

9 salt marshes. Acid phosphatase and $\beta$ - $\mathrm{N}$-acetylglucosaminidase presented significantly

10 higher EEA in Rosário than in Pancas, whereas the opposite occurred for peroxidase.

11 This was mainly attributed to differences in organic matter between the two sites. A

12 positive correlation between root biomass and EEA of hydrolases ( $\beta$-glucosidase, $\beta$ - $\mathrm{N}$ -

13 acetylglucosaminidase and acid phosphatase) was found, indicating a possible influence

14 of the halophyte in sediment microbial function. This would potentially affect metal

15 cycling in the rhizosphere through microbial reactions.

16

17 Keywords: enzyme activity, halophytes, metals, phytoremediation, salt marsh, Spartina

18 maritima.

19

20 Abbreviations: EEA (extracellular enzyme activity), $\beta$-N-acetyl-glucosaminidase

21 (chitobiase) 


\section{ACCEPTED MANUSCRIPT}

1

2

\section{Introduction}

Salt marshes usually receive high inputs of contaminants coming from nearby urban areas, river transport and tidal inundation. They are considered to act as sinks for contaminants, namely heavy metals (review by Williams et al., 1994; Doyle and Otte, 1997). Metals accumulate mainly in the sediments, especially in vegetated areas of the marsh (Caçador et al., 1996).

It has been shown that halophytes have a dominant role in the metal cycling in salt marshes (Otte, 1991; Caçador et al., 2000). The roots take up metals, which are mainly accumulated in root tissues and only a small fraction is translocated to the above ground parts of the plants (Alberts, 1990). When plants die, litter decomposition leads to the mobilisation of metals and their return to sediment, at a rate that is dependent on the type of tissue but also on plant species (Windham et al., 2003). Apart from direct uptake of metals, wetland plants contribute to metal removal through other important processes such as substrate stabilization, rhizosphere oxidation and supply of organic matter for microorganisms (Kosolapov et al., 2004).

Microbial activity in sediments is involved in several processes useful for bioremediation of metals, like metal precipitation by sulphate reduction and redox transformations of metals among others (Kosolapov et al., 2004). Wetland plants interact with microorganisms of the rhizosphere by supplying organic matter that is required for such reactions and thus providing an appropriate environment for metal cycling (Jacob and Otte, 2003). For instance, stimulated sulphate reducing bacteria activity caused by $\underline{\text { S. maritima }}$ colonisation was thought to be one of the reasons for variations in metal sulphides in salt marshes of Ría de Ortigueira, Spain (Otero and Macías, 2002). In fact, some phytoremediation strategies involve inoculation of plants with rhizosphere microbiota and arbuscular mycorrhiza (Khan, 2005). 


\section{ACCEPTED MANUSCRIPT}

Enzymes activities are a useful index of microbial activity (Sinsabaugh, 1994;

2 Ravit et al., 2003). Enzymes can exist extracellularly in sediments, attached to clay

3 minerals or complexed with humic colloids (Burns, 1982). Extracellular enzymes

4 excreted by fungi and bacteria effectively metabolize humic compounds reducing their

5 molecular weight, consequently increasing the solubility and mobility of these potential

6 carriers of heavy metals (Gramss et al., 1999). The enzyme activity assay gives the

7 maximum potential activity of enzymes occurring in sediment rather than the actual

8 enzyme activity (Alef and Nannipieri, 1995).

9 In this paper we compared the EEA (Extracellular Enzymatic Activity) of five

10 enzymes in sediments colonised by Spartina maritima in two salt marshes of the Tagus

11 estuary (Portugal) with marked differences in their characteristics such as sediment

12 parameters and metal contaminant levels (Caçador et al., 1999). Our aim was to

13 compare the possible influence of the plant on the microbial function of the rhizosphere

14 under different site conditions. This would help to elucidate how halophyte-

15 microorganism interactions may contribute for the potential use of halophytes in

16 phytoremediaton of metal contaminated environments.

2. Materials and Methods

\subsection{Site description}

Between February-March 2005 five sediment cores were collected in areas

22 colonised by Spartina maritima in each of two salt marshes of the Tagus estuary:

23 Rosário ( $\left.38^{\circ} 40^{\prime} \mathrm{N}, 9^{\circ} 01^{\prime} \mathrm{W}\right)$ and Pancas $\left(38^{\circ} 48^{\prime} \mathrm{N}, 8^{\circ} 55^{\prime} \mathrm{W}\right)$. Rosário is a mature salt

24 marsh (Valiela et al., 2000) with muddy sediments located in the southern part of the estuary, in the vicinity of urbanised and industrial areas. Pancas is a young salt marsh 


\section{ACCEPTED MANUSCRIPT}

1 (Valiela et al., 2000) with muddy-sand sediments located in the northeast part of the

2 estuary, within the Tagus Nature Reserve. Distance between these sites is about $18 \mathrm{~km}$.

3 The studied salt marshes contain extensive intertidal mudflat areas colonised by

4 halophyte plant communities dominated by Spartina maritima (Curtis) Fernald,

$5 \quad$ Halimione portulacoides (L.) Aellen, Sarcocornia fruticosa (L.) A. J. Scott and

6 Sarcocornia perennis (Mill.) A. J. Scott. These sites experience two tidal flushing a day

7 (for a more detailed description of the estuary see Caçador et al. (1996)). Rosário

8 presents higher levels of metal contamination than Pancas (Table 1, after Caçador and

9 Vale, 2001).

112.2 Sampling

12 Collection of samples was made at low tide. Sediment was removed using a

13 stainless steel corer with $6.8 \mathrm{~cm}$ inner diameter and $50 \mathrm{~cm}$ depth. In the field, cores were

14 sliced to separate the following segments: $0-5 \mathrm{~cm}, 10-15 \mathrm{~cm}$ and $40-45 \mathrm{~cm}$. These

15 segments were expected to be representative of surface sediment, sediment with high

16 root biomass and deep sediment with little or inexistent root influence, respectively.

17 Redox potential (Eh) and $\mathrm{pH}$ values of fresh sediment were determined in situ using a

18 HANNA pH/mV meter (HI 9025). The samples were placed in plastic bags and

19 transported to the laboratory refrigerated. Those samples for determination of enzymatic

20 activity were frozen at $-20^{\circ} \mathrm{C}$ until enzymatic analysis was carried out (Kuperman and

21 Carreiro, 1997). Root biomass was determined in fresh sediment separating root

22 material from sediment and then drying to constant weight at $70^{\circ} \mathrm{C}$ (Gross et al., 1991).

\subsection{Sediment parameters}




\section{ACCEPTED MANUSCRIPT}

Sediment ( $20 \mathrm{~g}$ ) was dried $48 \mathrm{~h}$ at $60^{\circ} \mathrm{C}$ and relative moisture calculated

2 (percentage of fresh weight). In order to determine organic matter content (LOI, loss on

3 ignition) $2 \mathrm{~g}$ of dry sediment was burned at $600^{\circ} \mathrm{C}$ for 2 hours.

4

5

6

\subsection{Enzyme activities in sediment}

Enzymatic activity of 5 enzymes (two oxidoreductases and three hydrolases)

was analysed: phenol oxidase, peroxidase, $\beta$-glucosidase, acid phosphatase and $\beta-\mathrm{N}$ -

acetylglucosaminidase (chitobiase). These enzymes are involved in metabolic processes

such as $\mathrm{C}$ cycling ( $\beta$-glucosidase, catalyzes the final step of cellulose degradation), $\mathrm{N}$

and $\mathrm{C}$ cycling ( $\beta-\mathrm{N}$-acetylglucosaminidase, hydrolyzes the glucosamine), $\mathrm{P}$ cycling

(acid phosphatase, hydrolyzes organic-P compounds) and decomposition of plant litter

(phenol oxidase, catalyzes polyphenol oxidation; and peroxidase, catalyzes the

oxidation of various compounds such as phenols and amines). We used the method

described in Ravit et al. (2003) with a modification in the incubation temperature and

without dilution of the supernatant. Sediment samples were prepared for analysis adding

$75 \mathrm{ml}$ of sodium acetate buffer ( $\mathrm{pH} 5$ ) to $5 \mathrm{~g}$ fresh sediment. The sample was mixed for

1 min to obtain the sediment slurry. The substrates used for $\beta$-glucosidase, acid

phosphatase and $\beta-\mathrm{N}$-acetylglucosaminidase (chitobiase) were p-Nitrophenyl- $\beta$-D-

glucopyranoside, $\mathrm{p}$-Nitrophenyl phosphate and p-Nitrophenyl-N-acetyl- $\beta$-D-

glucosaminide, respectively. All of them released p-nitrophenol (pNP) when hydrolized.

Two millilitres of substrate $(5 \mathrm{mM})$ was added to $2 \mathrm{ml}$ of the slurry in a test tube and incubated at $30^{\circ} \mathrm{C}$ in gentle agitation for $60 \mathrm{~min}$ ( $\beta$-glucosidase), $30 \mathrm{~min}$ (acid phosphatase) and 2 hours (chitobiase). After incubation the samples were centrifuged at $2000 \mathrm{rev} \mathrm{min}^{-1}$ for $15 \mathrm{~min}$ and $0.2 \mathrm{ml}$ of $1 \mathrm{~N} \mathrm{NaOH}$ was added immediately to stop the reaction and cause colour change. Determination of phenol oxidase and peroxidase activities was carried out using L-DOPA (L-3,4-dihydroxyphenylalanine) as substrate 
1 (5 mM) following the same procedure: $2 \mathrm{ml}$ slurry $+2 \mathrm{ml}$ substrate (adding $0.1 \mathrm{ml}$ of

$20.3 \% \mathrm{H}_{2} \mathrm{O}_{2}$ for peroxidase). Incubation time was $60 \mathrm{~min}$ for both enzymes, followed by

3 centrifugation. Absorbance of supernatant was read on a TECAN Absorbance

4 Microplate Reader (SPECTRA Rainbow) at $410 \mathrm{~nm}$ for pNP enzymes and at $460 \mathrm{~nm}$

5 for L-DOPA enzymes. Absorbance for phenol oxidase was substracted from absorbance

6 of peroxidase total (which assay gives the activity of peroxidase + phenol oxidase) in

7 order to calculate absorbance for peroxidase alone. Controls of sediment slurry and

8 substrate were made, and their absorbance subtracted from the absorbance read for each

9 sample. Enzymatic activity was expressed as $\mu$ moles product $g d r y w t^{-1} h^{-1}$.

$10 \quad 2.5$ Statistic analyses

Significant differences in soil characteristics between sites were tested using one-way ANOVA. Significant differences in extracellular enzymatic activities between the two sites at the different depths were compared using one-way ANOVA. The same analysis was used to test differences with depth at each site separately. This was followed by a Tukey- HSD test when appropriate. Pearson's coefficient was calculated to test correlation between activities of different enzymes and correlation between enzymes activities and soil characteristics.

\section{Results and discussion}

maritima in Rosário and Pancas are shown in Table 2. Sediment redox potential (Eh) was significantly higher $(\mathrm{p}<0.05)$ in Pancas, except on the surface, where Rosário showed significantly higher Eh. Organic matter (LOI) and moisture were significantly higher $(\mathrm{p}<0.05)$ in Rosário at every depth studied in areas colonised by $\underline{\text { S. maritima, }}$ 


\section{ACCEPTED MANUSCRIPT}

1 whereas $\mathrm{pH}$ was significantly higher in Rosário only at the root depth $(10-15 \mathrm{~cm})$. Root

2 biomass of $\underline{\text { S. maritima }}$ was significantly higher in Rosário than in Pancas $(\mathrm{p}<0.05)$.

3

4 The extracellular enzymatic activity (EEA) of peroxidase was much higher (up

5 to 10 fold) than the EEA of the other four enzymes at every depth studied (Figure 1).

6 The dominance of peroxidase over hydrolytic enzymes may indicate the presence of

7 refractory organic matter in the salt marsh (Sinsabaugh et al., 2003). Gramss et al.

8 (1999) demonstrated that extracellular enzymes released by fungi and bacteria, as well

9 as commercial enzymes including peroxidase and $\beta$-glucosidase, were able to

10 effectively metabolize soil humic extracts (to which heavy metal ions and xenobiotics

11 are potentially attached), reducing their molecular weight and consequently increasing

12 their solubility and motility. Therefore, high extracellular activity of peroxidase in

13 sediments colonised by $S$. maritima might influence the mobilization of metals in the

14 studied salt marshes. In addition to supplying plant litter for decomposition, the

15 halophyte may contribute to high EEA of peroxidase by the release of peroxidases from

16 plant roots (Salt et al., 1998). However, it should be taken into account that the EEA

17 assay gives the maximum potential activity of enzymes occurring in sediment rather

18 than the actual enzyme activity (Alef and Nannipieri, 1995).

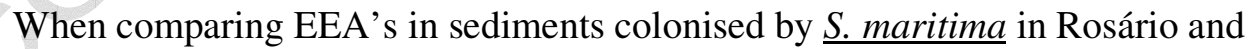

21 Pancas, significant differences were observed for peroxidase, acid phosphatase and

22 chitobiase $(\mathrm{p}<0.05)$ (Figure 1). Peroxidase presented higher EEA in Pancas than in

23 Rosário, whereas acid phosphatase and chitobiase presented higher EEA in Rosário than

24 in Pancas. Correlation coefficients between EEA's and sediment characteristics revealed

25 that acid phosphatase and chitobiase activities were positively correlated with organic

26 matter content and moisture (Table 3). In addition, chitobiase activity was positively 
1 correlated with $\mathrm{pH}$. A negative correlation occurred between EEA of peroxidase and

2 organic matter content. These results suggest that differences in the organic matter

3 content between the two sites could partly explain the observed pattern in extracellular

4 activities of the enzymes in areas colonised by S. maritima. Higher organic matter

5 content and moisture in sediment from Rosário seemed to be related to higher EEA's of

6 acid phosphatase and chitobiase (also influenced by higher $\mathrm{pH}$ ) in this salt marsh,

7 whereas peroxidase activity was higher in Pancas, where organic matter content of the

8 sediment was lower. Results from Caçador et al. (2004) showed that litter

9 decomposition in Pancas was faster than in Corroios, another salt marsh with

10 characteristics similar to Rosário (located about $12 \mathrm{Km}$ to the southwest from this)

11 (Caçador et al., 1999). This may be related to higher activities of peroxidase in Pancas,

12 as it is involved in the degradation of complex organic compounds. There was no

13 correlation between EEA's and redox potential of the sediment. This was surprising,

14 especially for phenol oxidase, that needs $\mathrm{O}_{2}$ for its activity. An oxygen limitation on

15 phenol oxidase is associated with inhibition of hydrolytic enzymes in peatlands through

16 accumulation of phenolic compounds (Freeman et al, 2001; Freeman et al. 2004). The

17 low EEA observed for phenol oxidase (in the same order of magnitude as the

18 hydrolases) is likely to be caused by $\mathrm{O}_{2}$ limitation in the sediment, since it is expected to

19 be scarce in salt marsh sediments. Although no reductive conditions were found in the

20 sediments studied (positive Eh) it should be taken into account that it does not indicate

21 abundance of $\mathrm{O}_{2}$, as other oxidant compounds could be present. Accumulation of

22 phenolic compounds due to restricted phenol oxidase activity would have important

23 consequences for the cycling of heavy metals in the salt marsh, since phenols are known

24 to bind metals (Ambrosi et al., 2003; Mota et al., 2005). 
Hydrolytic enzymes activities ( $\beta$-glucosidase, acid phosphatase and chitobiase)

2 were positively correlated with root biomass of S. maritima (Table 3). Microbial

3 activity is stimulated around plant roots through exudation of organic anions and sugars

4 (Ryan et al., 2001). Karjalainen et al. (2001) found that Lobelia dortmanna L., a

5 submersed plant species, enhanced microbial activity and biomass in sediments through

6 organic carbon release. Thus, it would be reasonable that higher root biomass would

7 result in higher exudation of organic compounds, enhancing microbial activity around

8 plant roots. Burke et al. (2002) found a positive interaction between a group of

$9 \quad$ Protobacteria and root biomass of Spartina patens and $\underline{\text { Phragmites australis in salt }}$

10 marsh sediments. The release of soluble sugars by roots supply the substrates needed by

$11 \beta$-glucosidase and chitobiase ( $\beta$-N-acetylglucosaminidase), probably inducing the

12 excretion of higher amounts of these enzymes by microorganisms (Burns, 1982). In

13 spite of this, $\beta$-glucosidase activity was not significantly higher in sediment from

14 Rosário, where S. maritima root biomass was significantly higher (Figure 1; Table 3).

15 This might be caused by an inhibition of this enzyme in the presence of higher metal concentrations in Rosário (Table 1) (Geiger et al., 1998). Exudation of phosphatases

17 from plant roots is one of the strategies used by plants to cope with P deficiency (Ryan et al., 2001). This might be a strategy of S. maritima as well, given the correlation found

19 between acid phosphatase activity and root biomass of the plant (Table 3). Ravit (2005)

20 concluded that, in salt marsh environments of the USA, the sediment microbial

21 community structure and function is determined by the interaction of hydrological

22 conditions and the effect of plant roots. From the observed results we deduce that $S$.

23 maritima roots could influence the extracellular enzymatic activity of the hydrolytic

24 enzymes analysed and, accordingly, it may affect the microbial function in the

25 rhizosphere of the plant in Tagus estuary salt marshes. Given the importance of 
1 microbially mediated reactions in metal cycling around plant roots in wetlands (Jacob

2 and Otte, 2003), and the proposed use of halophytes like S. maritima for

3 phytostabilization of metals in metal contaminated salt marshes (Reboreda and Caçador,

4 2007; Reboreda et al., In press), the halophyte-microorganism interactions arise as an

5 additional concern for phytoremediation studies. and acid phosphatase from Rosário. Still, enzymatic activities were in general lower in

9 the horizon $40-45 \mathrm{~cm}$, most likely as a consequence of low organic matter content and oxygen availability (Table 2). In Pancas, the lack of significant differences in EEA with depth $(\mathrm{p}>0.05)$ was surprising considering the 2-orders of magnitude change in root biomass and organic matter (Table 2). Other sediment parameters such as grain size

13 (muddy-sand in Pancas; Reboreda et al., in press) may have a stronger effect on 14 enzymes distribution (Kandeler et al., 2000).

In Rosário, EEA's of $\beta$-glucosidase and chitobiase were positively correlated with EEA of phenol oxidase (Table 4). This might suggest a similar behaviour of these enzymes, in organic matter rich/oxygen limited salt marshes, as that found by Freeman et al. (2001) and Freeman et al. (2004) in peatlands, which was described above. EEA of $\beta$-glucosidase also showed correlation with peroxidase activity. There were no significant correlations between EEA's of the studied enzymes in Pancas.

\section{Conclusions}

Sediments colonised by $S$. maritima show differences in some extracellular enzymes activities between salt marshes in the Tagus estuary, which appears to be 
1 the idea that $S$. maritima could influence to some extent the microbial function in the

2 rhizosphere, which in turn may potentially influence microbially mediated metal cycling

3 in the sediment. In addition, site characteristics seem to play a relevant role in

4 enzymatic activity as well, given the differences observed between the two sites.

5 Consequently, we suggest that halophyte-microorganism interactions are worthy of

6 further study for its usefulness in phytoremediation strategies.

7

\section{6. Acknowledgements}

9 This research was funded by "Fundação para a Ciência e Tecnologia, MECTIS

10 POCI/MAR/58548/2004". The authors are grateful to Dr. Beth Ravit for the

11 clarifications about the experimental procedure. Thank you to the anonymous referees

12 who contributed to improve the manuscript. 


\section{ACCEPTED MANUSCRIPT}

\section{6. References}

2

3 Alberts, J.J., Price, M.T., Kania, M., 1990. Metal concentrations in tissues of Spartina

4 alterniflora (Loisel.) and sediments of Georgia salt marshes. Estuarine Coastal and

5 Shelf Science 30, 47-58.

6

7 Alef, K., Nannipieri, P. (Eds.), 1995. Methods in Applied Soil Microbiology and

8 Biochemistry. Academic Press, London

9

10 Ambrosi, G., Formica, M., Fusi, V., Giorgi, L., Guerri, A., Micheloni, M., Paoli, P.,

11 Pontellini, R., Rossi, P., 2003. Heavy metal ion complexes with a simple phenolic

12 ligand. Solid state and solution studies. Inorganica Chimica Acta-Articles 356, 203-209.

14 Burke, D.J., Hamerlynck, E.P., Hahn, D., 2002. Interactions among plant species and

15 microorganisms in salt marsh sediments. Applied and Environmental Microbiology

16 68(3), 1157-1164.

17

18 Burns, R.G., 1982. Enzyme activity in soil: location and a possible role in microbial

19 ecology. Soil Biology and Biochemistry 14, 423-427.

21 Caçador, I., Costa, A.L., Vale, C., 2004. Carbon storage in Tagus salt marsh sediments.

22 Water, Air and Soil Pollution 4, 701-714. 


\section{ACCEPTED MANUSCRIPT}

1 Caçador, I., Vale, C., Catarino, F., 1996 Accumulation of $\mathrm{Zn}, \mathrm{Pb}, \mathrm{Cu}$ and $\mathrm{Ni}$ in

2 sediments between roots of the Tagus estuary salt marshes, Portugal. Estuarine Coastal

3 and Shelf Science 42(3), 393-403.

6 Caçador, I., Vale, C., Catarino, F., 1999. Relationships between metal concentrations

7 and organic matter content in the Tagus estuary salt marsh sediments. In: Lieth, H.,

8 Moschenko, M., Lohmann, M., Koyro, H-W., Hamdy A. (Eds.). Halophyte uses in

9 different climates I, Backhuys Publishers, Leiden, The Netherlands: 105-112.

11 Caçador, I., Vale, C., Catarino, F., 2000. Seasonal variation of $\mathrm{Zn}, \mathrm{Pb}, \mathrm{Cu}$ and $\mathrm{Cd}$

12 concentrations in the roots-sediment system of Spartina maritima and Halimione

13 portulacoides from Tagus estuary salt marshes. Marine Environmental Research 49(3),

$14 \quad 279-290$.

15 Caçador, I., Vale, C., 2001. Retention of Heavy Metals in Salt Marshes and Estuarine

16 Water Quality Metals in the Environment: Analysis by Biodiversity. MNV. Prasad (Ed.)

17 Marcel Dekker, Inc, New York: 95-116.

19 Doyle, M.O., Otte, M.L., 1997. Organism-induced accumulation of Fe, Zn and AS in

20 wetland soils. Environmental Pollution 96 (1), 1-11.

22 Freeman, C., Ostle, N.J., Fenner, N., Kang, H., 2004. A regulatory role for phenol

23 oxidase during decomposition in peatlands. Soil Biology and Biochemistry 36, 1663 -

241667. 
1 Freeman, C., Ostle, N.J., Kang, H., 2001. An enzymic 'latch' on a global carbon store.

2 Nature 409, 149.

3

4 Geiger, G., Furrer, G., Funk, F., Brandl, H., Schulin, R., 1999. Heavy metal effects on

5 beta-glucosidase activity influenced by $\mathrm{pH}$ and buffer systems. Journal of Enzyme

$6 \quad$ Inhibition $14(5), 365-379$.

7

8 Gramss, G., Ziegenhagen, D., Sorge, S., 1999. Degradation of soil humic extract by

9 wood- and soil-associated fungi, bacteria and commercial enzymes. Microbial Ecology

$10 \quad 37,140-151$.

11

12 Gross, M.F., Hardisky, M.A., Wolf, P.L., Klemas, V., 1991. Relationship between

13 aboveground and belowground biomass of Spartina alterniflora (smooth cordgrass).

14 Estuaries 14, 180-191.

15

16

17 Jacob, D.L., Otte, M.L., 2003. Conflicting processes in the wetland plant rhizosphere:

18

metal retention or mobilization? Water, Air and Soil Pollution 3, 91-104.

21 Kandeler, E., Tscherko, D., Bruce, K.D., Stemmer, M., Hobbs, P.J., Bardgett, R.D.,

22 Amelung, W., 2000. Structure and function of the soil microbial community in

23 microhabitats of a heavy metal polluted soil. Biology and Fertility of Soils 32 (5), 390-

24400. 


\section{ACCEPTED MANUSCRIPT}

1 Khan, A.G., 2005. Role of soil microbes in the rhizospheres of plants growing on trace

2 metal contaminated soils in phytoremediation. Journal of Trace Elements in Medicine

3 and Biology 18, 355-364.

4

5 Kosolapov, D.B., Kuschk, P., Vainshtein, M.B., Vatsourina, A.V., Wießner, A.,

6 Kästner, M., Müller, R.A., 2004. Microbial processes of heavy metal removal from

7 carbon-deficient effluents in constructed wetlands. Engineering of Life Science 4 (5),

$8 \quad 403-411$.

9

10 Kuperman, R.G., Carreiro, M.M., 1997. Soil heavy metal concentrations, microbial

11 biomass and enzyme activities in a contaminated grassland ecosystem. Soil Biology and

12 Biochemistry 29 (2), 179-190.

Mota, A.M., Cruz, P., Vilhena, C., Gonçalves, M.L.S., 2005. Influence of the sediment on lead speciation in the Tagus estuary. Water Research 39, 1451-1460.

Otero, X.L., Macias, F., 2002. Variation with depth and season in metal sulphides in salt

19 marsh soils. Biogeochemistry 61 (3), 247-268.

21 Otte, M.L., Besterbroer, S.J., Van der Linden, J.M., Rozema, J., Broekman, R.A., 1991.

22 A survey of $\mathrm{Zn}, \mathrm{Cu}$ and $\mathrm{Cd}$ concentrations in salt marsh plants along the Dutch coast.

23 Environmental Pollution 72, 175-189. 


\section{ACCEPTED MANUSCRIPT}

1 Ravit, B., 2005. Macrophytes and microbes: Spartina alterniflora and Phragmites

2 australis affect brackish sediment microbial community structure and function.

3 Dissertation Abstracts International Part B: Science and Engineering 66 (5), 2488.

4

5 Ravit, B., Ehrenfeld, J.G., Haggblom, M.M., 2003. A comparison of sediment microbial

6 communities associated with $\underline{\text { Phragmites australis }}$ and Spartina alterniflora in two

7 brackish wetlands of New Jersey. Estuaries 26(2B), 465-474.

8

9 Reboreda, R., Caçador, I., 2007. Halophyte vegetation influences in salt marsh retention capacity for heavy metals. Environmental pollution 146, 147-154.

12 Reboreda, R., Caçador, I., Pedro, S., Raposo, P., In press. Mobility of metals in salt

13 marsh sediments colonised by Spartina maritima (Tagus estuary, Portugal).

14 Hydrobiologia.

16 Rieling, T., Gerbersdorf, S., Stodian, I., Black, H.J., Dahlke, S., Köster, M.,

17 Meyercordt, J., Meyer-Reil, L-A., 2000. Benthic microbial decomposition of organic matter and nutrient fluxes at the sediment-water interface in a shallow coastal inlet of the southern Baltic Sea (Nordrügensche Boden). In: Flemming, B.W., Delafontaine, M.T., Liebezeit, G. (Eds.) Muddy Coast Dynamics and Resource Management, Elsevier

21 Science BV, Amsterdam.

23 Ryan, P.R., Delhaize, E., Jones, D.L., 2001. Function and mechanism of organic anion

24 exudation from plant roots. Annual Review of Plant Physiology and Plant Molecular

25 Biology 52, 527-560. 
2 Salt, D.E., Smith, R.D., Raskin, I., 1998. Phytoremediation. Annual Reviews of Plant

3 Physiology and Plant Molecular Biology 49, 643-668.

5 Sinsabaugh, R.L., 1994. Enzymatic analysis of microbial pattern and process. Biology 6 and Fertility of Soils 17 (1), 69-74.

8 Sinsabaugh, R.L., Saiya-Cork, K., Long, T., Osgood, M.P., Neher, D.A., Zak, D.R.,

9 Norby, R.J., 2003. Soil microbial activity in a Liquidambar plantation unresponsive to

$10 \mathrm{CO}_{2}$-driven increases in primary production. Applied Soil Ecology 24, 263-271.

12 Williams, T.P., Bubb, J.M., Lester, J.N., 1994. Metal accumulation within salt marsh

13 environments: a review. Marine Pollution Bulletin 28 (5), 277-290.

15 Windham, L., Weis, J.S., Weis, P., 2003. Uptake and distribution of metals in two

16 dominant salt marsh macrophytes, Spartina alterniflora (cordgrass) and Phragmites

17 australis (common reed). Estuarine, Coastal and Shelf Science 56, 63-72.

19 Valiela, I., Cole, M., McClelland, J. Cebrian, J., Joye, S.B. 2000. Role of salt marshes

20 as part of coastal landscapes. Concepts and Controversies in Tidal Marsh Ecology (eds)

21 Weinstein, M.P. \& Kreeger, D.A. Kluwer Academic Publishers. London 
1

2 Figure caption

3

$4 \quad$ Figure 1. Extracelullar enzymatic activities (EEA) $\left(\mu\right.$ moles $^{-1} \mathrm{~g}$ dry weight $\left.{ }^{-1}\right)$ in three

5 depths of sediment at Rosário and Pancas sites colonised by Spartina maritima

$6 \quad$ (mean $\pm \mathrm{SD})$. *Significant differences $(\mathrm{p}<0.05)$ between sites.

7 
Figure 1

2

3

4

5

$\square \quad$ Rosário $\square \quad$ Pancas
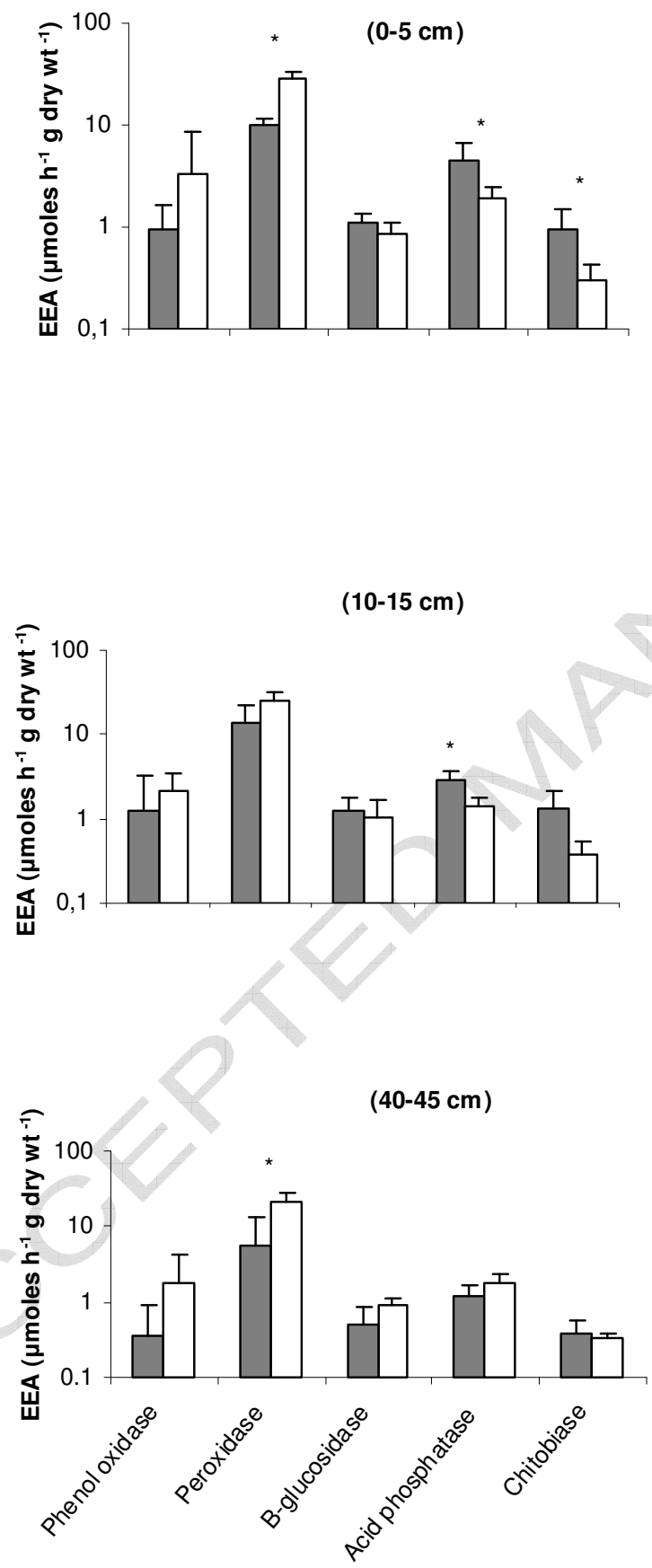
1 Table 1. Concentrations (mean \pm standard deviation) of $\mathrm{Zn}, \mathrm{Pb}, \mathrm{Cu}$ and $\mathrm{Cd}\left(\mu \mathrm{g} \mathrm{g}^{-1}\right.$ dry

2 weight $)$ in surface sediments $(0-5 \mathrm{~cm})$; intermediate rooted sediment layers $(10-15 \mathrm{~cm})$

3 and deeper layers $(40-45 \mathrm{~cm})$ in areas colonised by Spartina maritima, from Pancas and

4 Rosário salt marshes (after Caçador \& Vale, 2001)

5

6

7

\begin{tabular}{|c|c|c|c|c|c|}
\hline Sites & Depth (cm) & $\mathrm{Zn} \mu \mathrm{g} \mathrm{g^{-1 }} d w$ & $\mathrm{~Pb} \mu \mathrm{g} \mathrm{g}^{-1} \mathrm{dw}$ & $\mathrm{Cu} \mu \mathrm{g} \mathrm{g}^{-1} \mathrm{dw}$ & $C d \mu g^{-1} d w$ \\
\hline \multirow[t]{3}{*}{ Pancas } & $(0-5)$ & $95 \pm 17$ & $42 \pm 4$ & $22 \pm 3$ & $1.1 \pm 0.2$ \\
\hline & $(10-15)$ & $17 \overline{7} \pm 18$ & $53 \pm 4$ & $33 \pm 6$ & $1.3 \pm 0.1$ \\
\hline & $(40-45)$ & $93 \pm \overline{5}$ & $43 \pm 9$ & $14.7 \pm 3$ & $0.4 \pm 0.1$ \\
\hline \multirow[t]{3}{*}{ Rosário } & $(0-5)$ & $402 \pm 27$ & $395 \pm 16$ & $51 \pm 2$ & $1.2+0.2$ \\
\hline & $(10-15)$ & $116 \overline{9} \pm 74$ & $577 \pm 21$ & $78 \pm 15$ & \pm 0.2 \\
\hline & $(40-45)$ & $98 \pm \overline{10}$ & $55.3 \pm 11$ & $12 . \overline{7} \pm 3$ & $0.4 \pm 0.1$ \\
\hline
\end{tabular}

8 


\section{ACCEPTED MANUSCRIPT}

1 Table 2. Eh (mV), pH, organic matter (Loss on Ignition, \%), moisture (\%) and root

2 biomass $\left(\mathrm{g} \mathrm{m}^{-2}\right)$ in sediments from Rosário and Pancas colonised by $S$. maritima at three

3 sediment horizons (mean $\pm \mathrm{SD}$ ).

4

\begin{tabular}{lllllrr}
\hline & Depth & Eh $(\mathbf{m V})$ & $\mathbf{p H}\left(\mathbf{1 4}^{\mathbf{0}} \mathbf{C}\right)$ & LOI & Moisture (\%) & Biomass $\left(\mathbf{g ~ m}^{-2}\right)$ \\
\hline \multirow{4}{*}{ Pancas } & $0-5 \mathrm{~cm}$ & $84.0 \pm 24.7^{*}$ & $5.9 \pm 0.5$ & $10.3 \pm 0.6^{*}$ & $52.3 \pm 0.7^{*}$ & $264.6 \pm 26.3^{*}$ \\
& $10-15 \mathrm{~cm}$ & $80.9 \pm 23.2^{*}$ & $5.9 \pm 0.4^{*}$ & $8.0 \pm 0.1^{*}$ & $50.7 \pm 1.7^{*}$ & $681.0 \pm 9.6^{*}$ \\
& $40-45 \mathrm{~cm}$ & $76.3 \pm 11.9^{*}$ & $5.5 \pm 1.3$ & $0.6 \pm 0.7^{*}$ & $16.4 \pm 0.6^{*}$ & $9.6 \pm 3.0^{*}$ \\
& $0-5 \mathrm{~cm}$ & $107.4 \pm 23.0^{*}$ & $5.5 \pm 0.1$ & $19.0 \pm 5.9^{*}$ & $64.1 \pm 5.0^{*}$ & $798.8 \pm 50.2^{*}$ \\
Rosário & $10-15 \mathrm{~cm}$ & $29.0 \pm 7.0^{*}$ & $6.7 \pm 0.2^{*}$ & $14.5 \pm 2.0^{*}$ & $60.0 \pm 2.8^{*}$ & $1305.0 \pm 124.3^{*}$ \\
& $40-45 \mathrm{~cm}$ & $20.0 \pm 6.8^{*}$ & $5.8 \pm 0.1$ & $11.8 \pm 2.1^{*}$ & $49.7 \pm 8.5^{*}$ & $31.8 \pm 6.0^{*}$
\end{tabular}

5

*Significant differences between sites (one-way ANOVA, $\mathrm{p}<0.05$ ).

6

7 


\section{ACCEPTED MANUSCRIPT}

1 Table 3. Correlation coefficients (Pearson's) between sediment characteristics and

2 extracellular enzymatic activities of phenol oxidase, peroxidase, $\beta$-glucosidase, acid

3 phosphatase and chitobiase in salt marsh sediments colonised by Spartina maritima.

\begin{tabular}{|c|c|c|c|c|c|}
\hline & Eh $(\mathrm{mV})$ & $\mathrm{pH}$ & LOI $(\%)$ & Moisture $(\%)$ & Biomass $\left(\mathrm{g} \mathrm{m}^{-2}\right)$ \\
\hline Phenol ox. & 0.48 & -0.01 & -0.38 & -0.17 & -0.13 \\
\hline Peroxidase & 0.46 & 0.00 & $-0.54^{*}$ & -0.31 & -0.11 \\
\hline$\beta$-glucosidase & 0.32 & 0.46 & 0.26 & 0.31 & $0.86^{* *}$ \\
\hline Phosphatase & 0.47 & -0.05 & $0.70^{* *}$ & $0.51^{*}$ & $0.58^{*}$ \\
\hline Chitobiase & -0.17 & $0.57 *$ & $0.69 *$ & $0.59^{*}$ & $0.88^{* *}$ \\
\hline
\end{tabular}

$4 *$ Correlation is significant at the 0.05 level.

$5 * *$ Correlation is significant at the 0.01 level. 


\section{ACCEPTED MANUSCRIPT}

1 Table 4. Correlation between the activities of phenol oxidase, peroxidase, $\beta$ -

2 glucosidase, acid phosphatase and chitobiase in sediments of Rosário and Pancas

3 colonised by S. maritima (Pearson's Correlation).

4

\begin{tabular}{|c|c|c|c|c|c|c|}
\hline & Enzyme & Phenol ox. & Peroxidase & $\beta$-gluc & Phosphatase & Chitobiase \\
\hline \multirow{5}{*}{ 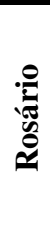 } & Phenol ox. & & & & \multirow{6}{*}{0.530} & \\
\hline & Peroxidase & 0.454 & & & & \\
\hline & $\beta$-glucosidase & $0.591^{*}$ & $0.650^{*}$ & & & \\
\hline & Phosphatase & 0.211 & 0.198 & 0.398 & & \\
\hline & Chitobiase & $0.707^{* * *}$ & 0.473 & $0.796^{* *}$ & & \\
\hline \multirow{5}{*}{$\begin{array}{l}\text { స్ } \\
\text { స్ }\end{array}$} & Phenol ox. & & & & & \\
\hline & Peroxidase & 0.497 & & & & \\
\hline & $\beta$-glucosidase & 0.089 & -0.230 & & & \\
\hline & Phosphatase & 0.025 & 0.192 & -0.046 & & \\
\hline & Chitobiase & -0.079 & 0.328 & 0.204 & 0.033 & \\
\hline
\end{tabular}

